This is an Accepted Manuscript of an article published by Taylor \& Francis in International Review of Sociology on 01 November 2016, available online:

http://www.tandfonline.com/10.1080/03906701.2016.1244952

Please cite as :

Godin, Benoît. 2016. "Official statisticians as conceptual innovators." International Review of Sociology 26 (3): 440-456. https://doi.org/10.1080/03906701.2016.1244952. 


\section{Official Statisticians \\ as Conceptual Innovators}

To be published in

International Review of Sociology

Special issue on "European Politics of Numbers: Sociological Perspectives on Official Statistics in Europe”, Guest editor: Francesco Antonelli 


\begin{abstract}
Statistics are impossible without concepts. As the sociologist of invention Colum Gilfillan put it in 1952, "counting begins with definition of the thing to be counted". This article is concerned with statistics on science, technology and innovation (STI). It documents how official statisticians have, over time, defined the concepts used for measurement.

Debates on definitions of the concepts measured started at the very beginning of STI measurement in the first half of the twentieth century. Then, from the early 1960s onward, methodological manuals were developed to conventionalize the definitions. This article claims that the manuals did not have the expected result. They did not stabilize the definitions and the statistics based thereupon.
\end{abstract}




\section{Introduction}

The OECD has produced methodological manuals for measurement of science, technology and innovation for more than fifty years. The Frascati manual on research and development $(R \& D)$ is the best-known of these documents, the first edition having been produced in 1962. In 2015, the manual reached its seventh edition. More recently, the organization expended similar efforts on the measurement of innovation. The Oslo manual, first produced in 1992, is now in a third revision.

In the last five years an entirely new task has occupied the OECD. The. organization gave itself the mandate of reconsidering concepts used for measurement, as it had never done so intensively before. Constant revisions of and amendments to the manuals had been conducted previously, but now the organization is looking critically at the concepts used in terms of the difficulties involved in their implementation and interpretation.

This article is concerned with the concepts measured or the concepts behind the measurements. The article takes seriously the suggestion of sociologist of invention Colum Gilfillan that "counting begins with definition of the thing to be counted" (Gilfillan, 1952: 368). More specifically, the concepts of research and of innovation are studied by examining the official manuals developed for their measurement: the Frascati manual on new knowledge, and the Oslo manual on new applications.

The Frascati manual is, one could say, well standardized. The definition of research used over the last five decades is similar from one edition to another. In contrast, the Oslo manual is more recent, and the definition of innovation is changing with every new edition. A comparison of the two manuals brings to light the conditions required for standardization, but also the limits of standardization. Standardization is not enough to stabilize definitions. Other social factors must be taken into consideration.

\section{The Need for Standardization}

Official measurement of science, technology and innovation is over one hundred years old (Godin, 2005; 2006a; 2007). Before the OECD came on the scene in the 1960s, 
two situations prevailed with regard to the concepts used for measurement. The first was the absence of a definition of the concepts proper, an absence also notable at the OECD. For example, the first edition of the Frascati manual had no definition of research. Research was defined by contrasting it to routine work: "The guiding line to distinguish R\&D activity from non-research activity is the presence or absence of an element of novelty or innovation. Insofar as the activity follows an established routine pattern it is not R\&D. Insofar as it departs from routine and breaks new ground, it qualifies as R\&D” (OECD, 1962: 16).

Before the 1960s, research was often measured using a "liberal interpretation". "What is research?" was left to the questionnaire respondent to decide (National Research Council, 1920: 45; National Research Council, 1941: 173; Dominion Bureau of Statistics, 1941). Consequently, any studies that used the survey numbers were of questionable quality (Holland and Spraragen, 1933; Perazich and Field, 1940): "The use of this information for statistical analysis has therefore presented several difficult problems and has necessarily placed some limitations on the accuracy of the tabulated material" (Perazich and Field, 1940: 52).

This problem was not limited to industrial research. In the case of publicly funded research, statisticians used whatever date they could find. They defined research by way of categories, or using lists of activities designed to help respondents decide what to include in the questionnaire responses. No disaggregated data were available for calculating statistical breakdowns by categories. Many statisticians used proxies instead. For example, in his well-known report Science: The Endless Frontier, Vannevar Bush's statistics were derived by equating college and university research with basic research, and considering industrial and government research to be applied research (Bush, 1945). This was also how the first edition of the Frascati manual defined research: by way of the categories included in the concept.

The second situation with regard to the concepts used for measurement was the absence of consensus on definitions, when definitions existed at all. Such was the case with innovation. In the 1970s, many stressed that innovation is a fuzzy concept, to the 
point that some suggested not using the word in surveys. ${ }^{1}$ The OECD was no exception: "The concept of innovation is extremely difficult to define" - the French version talks of a fuzzy concept: “Le concept d'innovation est extrêmement flou” (OECD, 1972 : 4; 1978: 26).

The semantic difficulties are twofold. First, innovation can be defined broadly or narrowly. Most often innovation is limited to technological innovation. This is the standard representation. But to some, it includes non-technological innovation as well. Second, innovation is defined either objectively or subjectively. Innovation can be a world first (a world premiere) or use with respect to an organization (one organization innovates with regard to its past behaviour, although others have adopted the invention before). From the very beginning, officials, as we will see, considered both objective and subjective aspects in their definition of innovation. Over time, they also extended the definition to include non-technological innovation, with ensuing difficulties of interpretation.

There are also measurement problems with innovation. This fact was admitted long ago, and the situation has not improved in recent decades. In the 1970s, four studies funded by the National Science Foundation identified many of the problems of measurement, among them the fact that few firms have records of their innovation activities for accounting purposes, hence the impossibility of measuring innovation expenses (Roberts and Romine, 1974; Hildred and Bengston, 1974; Posner and Rosenberg, 1974; Fabricant et al., 1975). As a consequence, and for a long period, officials as well as scholars satisfied themselves using proxies like R\&D as indicators of innovation activities. They had a well-known model as precedent in this regard. The "linear model of innovation" postulates that innovation starts with basic research, followed by applied research, then development (Godin, 2006c).

\footnotetext{
1 "Like all analytical concepts, the terms 'invention, innovation, and diffusion' lose some of their preciseness when one attempts to apply them to historical facts" (Scoville, 1951: 347). Innovation "lacks precise definition" (Maclaurin, 1955). "Innovation has come to mean all things to all men, and the careful student should perhaps avoid it wherever possible, using instead some other term" (Ames, 1961: 371); "We shall do better without the word innovation" (Machlup, 1962: 179). "Every change becomes an innovation simply because it has not been done before ... Such a definition sterilizes the term innovation" (Becker and Whisler, 1967: 463). "The use of the term innovation is counterproductive" because each individual has his or her own interpretation. "It may be useful to drop the term 'technological innovation' for purposes of survey design” (Roberts and Romine, 1974: 4).
} 
The above two situations can be explained by two facts. On one hand, in the first decades of the twentieth century, research was first of all an academic category, and its application to other institutions, above all businesses, was far from evident or accepted (Godin and Schauz, 2016). On the other hand, innovation was for centuries a (contested) social category that was just starting to become, with no precedent yet, a category of knowledge (Godin, 2015). Methodological manuals were developed to standardize and conventionalize these situations.

\section{Research}

Official measurement of research started in the 1920s at the National Research Council in the US, established in 1916 as an advisory body to the government. As part of its advisory role, the Council developed directories on research in the United States, covering industry, university and other institutions (Godin, 2013). This task was continued in the 1940s by the National Resources Planning Board (which created a roster of scientific personnel), and particularly by the National Science Foundation in the 1950s. In between, several federal government measurements were conducted (National Resources Committee, 1938; Bush, 1945; President’s Scientific Research Board, 1947), including those at the Department of Defense (Anthony, 1952; Dearborn et al., 1953; Department of Defense, 1953a; 1953b).

From the very first official measurement exercises on research, the motivation was not measuring per se, but rather locating available research facilities for the war effort. ${ }^{2}$ "In these early efforts, the primary interest was not so much in the magnitude of the dollars going into scientific research and development, either in total or for particular agencies and programs, but in identifying the many places where research and development of some sort or other was going on”, to identify overlaps among agencies and programs (Shapley, 1959: 8). For example, in the early 1950s the US Department of Defense Research and Development Board conducted a survey of industrial research to enable the government to locate available resources in the event of war, that is, to "assist

\footnotetext{
${ }^{2}$ To academics like James Cattell, it was initially locating the best researchers to fund (Godin, 2007).
} 
the military departments in locating possible contractors for R\&D projects” (Bureau of Labor Statistics, 1953: 1, 51-52).

However, the surveys were never used for this purpose (Baxter, 1946: 126-35). Nevertheless, the national framework - measuring research in the overall economy gave rise to a conception of research as a "whole” (Godin and Schauz, 2016). The concept of research applies to every institutional sector of the economy - university, government and industry.

The OECD entered the scene in 1962 with definitions borrowed from the National Science Foundation, whose definitions were in turn based on those of the Department of Defense. The early measurements of research at the OECD were able to count on the experience of several decades of work.

Every OECD methodological manual has more or less the same structure. The manuals begin by offering a conceptual framework to guide measurement. In the case of the Frascati manual on research, the framework is the institutional approach of the System of National Accounts. Statistics are collected according to four institutional units: the three units of the System of National Accounts - business, government and non-profit - to which is added the higher education sector. Then the manuals propose a definition of the main concept to be measured, followed by classification or categorization of the concept, again by way of definitions. The main categories that define the concept of research are basic research, applied research and development. These categories serve to decide what to include in measurements, but also what activities to exclude, like innovation.

These three categories or types of research are based on the expected use of the results, how far ahead in time results may occur, and how broad the range of application is (OECD, 2015: 53). Basic research and applied research have been two contested categories for decades (Godin, 2003). To a certain extent, namely to resolve the controversy, two sub-categories are added to basic research in the Frascati manual: pure and "oriented", the latter referring to expectation of applications (OECD, 2015: 50-51). Development - or rather experimental development, to distinguish it from product development and pre-production development (OECD, 2015: 51-52) - “is systematic work, drawing on knowledge gained from research and practical experience and 
producing additional knowledge, which is directed to producing new products or processes or to improving existing products or processes” (OECD, 2015: 51).

In the OECD view, "Research and development (R\&D) comprise creative and systematic work undertaken in order to increase the stock of knowledge - including knowledge of humankind, culture and society - and to devise new applications of available knowledge” (OECD, 2015: 44). This definition has been relatively stable over time. $^{3}$

What must be mention here is that development shares place with research in the $\mathrm{R} \& \mathrm{D}$ acronym. To the OECD, research is research and development R\&D. The D started as a subcategory of research, on a par with basic research and applied research (before 1945), but entered into the R\&D acronym for several reasons, the first being its industrial connotation. The concept has three main purposes. The first is organizational. It corresponds to the main type of research conducted in industry, to research divisions in firms, and to entire organizations that define themselves according to both research and development. The second purpose is analytical and statistical. Policy makers, consultants, statisticians and scholars developed taxonomies identifying development as a separate and distinct category of research and as a step in the process of economic growth. The third purpose is political (Godin, 2006b):

- Prestige: adding development to research to show larger expenditures.

- Public funding: including development in research expenditures to get a greater amount of money from public funds (e.g.: tax credits).

In the 2010s, after fifty years of measurement standards, the OECD began to study a series of problems associated with the definitions used for measurement purposes (OECD, 2014a; 2014d). There were difficulties of application, so it was said, because of varying interpretations and different languages; hence the difficulty of international comparisons. In May 2014, a revision group therefore proposed conceptual changes to the definitions used in the Frascati manual (OECD, 2014a). There were five proposed 
options for conceptual change, ranging from no change to the definition of research to substantial changes:

- No change. This option was justified by the necessity to maintain historical consistency in the definition. Changes may "jeopardize the consistency of the definition” and bring “confusion” among producers and users.

- Minor changes, provided that the impact on statistics is zero. Otherwise, changes "Could be interpreted by users as making the definition more restrictive".

- Selected and "surgical" changes in "obsolete, misleading or unclear" terms (like systematic; see below). According to the revision group, "Most users will not pay much attention to the new descriptions once they could be reassured that the definitions themselves will be kept unchanged".

- Substantial changes in meaning - but not in the wording. Put differently, it is a matter of "Deliver[ing] the same message by using a different word".

- Substantial changes, that take in consideration varying interpretations over time.

In the end the consensus among OECD member countries was for a "clarification of the definition of R\&D...with only minor cosmetic changes, namely setting out more explicitly the fundamental criteria" which define research and "using a more appropriate language", but not changing the definition of research. As a result, the definition of research in the 2015 edition of the Frascati manual remains essentially the same as that in the 1970 edition. The definition is "clearer and more precise", but still "consistent with the definition of R\&D used in the previous edition” (OECD, 2015: 21). As the OECD Secretariat put it: "One important point to note is that the revised definition should not bring about by itself a different level of GERD [Gross expenditures on R\&D] estimates” (OECD, 2014b: 4).

\footnotetext{
${ }^{3}$ The definition in the 1970 edition of the Frascati manual (the 1962 edition had no definition of research) reads as follows: "Creative work undertaken on a systematic basis to increase the stock of scientific and technical knowledge and to use this stock of knowledge to devise new applications” (OECD, 1970: 31).
} 
The latest edition of the Frascati manual repeats again and again the objective of consistency with previous editions: "Every effort was made to minimise the potential need for revisions in major statistical R\&D indicator time series.... As few changes as possible [were made] so that there remains stability in the core historical series" (OECD, 2015: 21-22); "The core definitions of R\&D are unchanged...apart from minor changes in language” (OECD, 2015: 24).

The real innovations were twofold. First, a chapter titled "Concepts and Definitions for Identifying R\&D” was constructed. The chapter brings together the conceptual and definitional issues that had been dispersed over several chapters in the previous editions - the definitions of the sub-components of R\&D (basic, applied, development), and the demarcation or boundary between research activities -, adding a series of "core criteria" for identifying R\&D activities. Here lies the second innovation. Five criteria are discussed to describe what R\&D is - and what R\&D is not (OECD, 2015: 46-48). These criteria were "present in the previous edition, but did not appear in the same place to help interpret the R\&D definition” (OECD, 2015: 24):

- Novelty. This problem involves the business sector above all. Research in the university sector is expected to be entirely new. However, in the business sector, novelty should be assessed with respect to the whole industry (not previously done elsewhere in the industry). As a consequence, the Frascati manual suggests the following definition of novelty: "Increase in knowledge beyond the level of awareness achievable by the performers".

- Creativity. Creativity is defined, as in the previous editions, as originality and it is contrasted to routine work. Routine work or "ordinary work" is established methodologies, principles and models. The manual only adds that research requires the presence of a researcher. In the end, the concept of creativity remains fuzzy and non-theorized, as it has always been (Godin, 2014).

- Uncertainty. This concept refers to change "when the solution to a problem is not readily apparent”, and to uncertainty about the outcome or the resources (costs) or time needed. 
- Systematicness. The previous editions of the Frascati manual understood systematic activity as "organized" activity conducted in a formal and continuous way, namely in the laboratory (Godin, 2005). The latest edition of the manual brings in the notion of "project". Project, as a criteria for separating R\&D from other activities, had not been defined before then. The manual suggests the following definition: project refers to "Specific objectives and expected output" or "Specific goals and a budget". A project is conducted in a planned way, with accounting records available. In the latest edition of the Frascati manual, systematic is a term that also appears explicitly in the definition of development.

- Transferability/reproducibility. The concept means potentially transferable among researchers. The knowledge produced as a result of research must be codified and recorded, not tacit.

To sum up the five criteria: research is "aimed at new findings based on original concepts (and their interpretations) or hypotheses. It is largely uncertain regarding its final outcome (or at least regarding the quantity of time and resources needed to achieve it), it is planned for and budgeted (even when carried out by individuals), and it is aimed at producing results that could be either freely transferred or traded in the marketplace" (OECD, 2015: 45).

Overall, the specific conceptual changes to the Frascati manual concern, among other things, the criteria on which the definition is based, but not the definition itself. The five criteria do not affect the definition, which remains the same, but, contrary to the OECD claim, the criteria would certainly affect the statistics, if taken seriously. What goes into the numbers is a lot more precisely defined now.

\section{Innovation}

Among the activities excluded from research in the Frascati manual is innovation, a type of activity that the OECD called "non-research activities" (OECD, 1981). This was always stated explicitly in previous editions. As early as 1976 Keith Pavitt from the 
Science Research Policy Unit (SPRU) complained about this as follows (OECD, 1976: 34):

\begin{abstract}
Statistics on R\&D have inherent limitations.... They do not measure all the expenditures on innovative activities.... In particular, they do not measure the expenditures on tooling, engineering, manufacturing and marketing start-up that are often necessary to turn R\&D into economically significant technical innovations. Nor do they measure the informal and parttime innovative activities that are undertaken outside formal R\&D laboratories.... They do not indicate the objectives of R\&D activities, for example, products or processes.... They do not measure outputs, either in terms of knowledge, or in terms of new or better products and production processes.
\end{abstract}

The purpose of the Oslo manual is to extend the OECD measurements to innovation, namely the later phases of development for pre-production, production and distribution. Like the Frascati manual, the Oslo manual contains a conceptual framework to guide measurement, that of "institutional environment” or system approach. Innovation is a process composed of different actors in interaction. While the framework of the Frascati manual (the System of National Accounts) is an official and wellconventionalized framework, the system approach is far from crystallized. It remains a framework in progress, if any.

Having proposed a conceptual framework to guide the measurement, and again like the Frascati manual, the Oslo manual defines the categories that the concept covers. The latest edition includes technological innovation, organizational innovation and marketing innovation (OECD, 2005).

Unlike research, there was little prior experience in the measurement of innovation when the OECD entered the field in the early 1990s, or at the least the experiments conducted were quite recent (Godin, 2002). Producing standards was thus audacious but, in the light of present difficulties, perhaps premature. To the OECD, “An innovation is the implementation of a new or significantly improved product (good or service), or process, or a new marketing method, or a new organizational method (in business practice, workplace organization or external relations)” (OECD, 2005: 46).

Such a definition has its roots in the very first studies the OECD conducted in the 1960s. For example, in Government and Technical Innovation, a document produced for the second ministerial conference on science, "Technical innovation is the introduction into a firm, for civilian purposes, of worthwhile new or improved production processes, 
products or services which have been made possible by the use of scientific or technical knowledge” (OECD, 1966: 9). Gaps in Technology, a study that followed the ministerial conference, defined (and measured) technological innovation (which "requires development work, together with manufacturing and market activities”) in terms of member countries' performance on two aspects: "being first to commercialize new products and production processes successfully" and the "level and rate of increase in the use [diffusion] of new products and production processes” (OECD, 1968: 14). Again, in The Conditions for Success in Technological Innovation published in 1971, innovation is defined as "Bringing invention to its first successful commercial use” (OECD, 1971: 19).

Given the market orientation of the definition, the current national surveys based on the Oslo manual apply to business firms only - in contrast to surveys of research. This is one of the challenges addressed today. The idea is being considered of extending the definition to non-business sectors like the public sector, education and citizens as innovators (OECD, 2014c)

Like research, the concept of innovation came under scrutiny in the 2010s. The OECD launched what it called scoping or cognitive testing, namely assessments or review exercises on the concepts and definitions used for measurement (OECD, 2012; 2013; 2014b; 2016a-e). The exercises were based on the decades-long recognition that innovation is a subjective concept. "What matters is not the actual date of invention but the perception [my italics] of novelty" (Rogers, 1972: 89); ${ }^{4}$ innovation "may be new under the sun...or new only under this roof” (Kelly et al., 1974: ii). The exercises were also based on the fact that innovation too is an evaluative concept. ${ }^{5}$ And the fact that

\footnotetext{
4 "It really matters little, as far as human behavior is concerned, whether or not the idea is objectively new as measured by the amount of time elapsed since its first use or discovery. It is the newness of the idea to the individual that determines his reaction to it” (Rogers, 1962: 13).

5 "Researchers have implicitly assumed that to adopt innovations is desirable behavior [rational] and to reject innovations is less desirable" [irrational] (Rogers, 1962: 142). "The most outstanding feature of innovation is its mysteriousness.... Many problems arise in defining innovation...because of the value judgment attached to the term.... The difficulty here is that most of us expect an innovation to be something good” (Knight, 1967: 478)."One of the vogue words these days is innovation. For some people it is even more - it is a value word that implies something good and positive” (Holt, 1971: 235)."Innovation tends to be viewed in positive terms socially. It is a good thing to advocate and to participate in. For the most part, researchers have assumed that innovation is good, and have sought to determine the conditions under which innovation takes place, the conditions that facilitate its diffusion, and the characteristics which distinguish more innovative individuals, groups and organizations from less innovative ones. One implicit assumption appears to be that research should foster innovation... Rarely if ever is not adopting an innovation considered to be a possibly important, adaptive strategy” (Kimberly, 1981: 84-85; 88).
} 
innovation is an "emotive word" (OECD, 2012: 12). In consequence, countries adopt the definitions in different ways, making the concept "difficult to understand and interpret in different languages” (OECD, 2012: 13).

The conceptual challenges are many. Again, novelty is one. The Oslo manual defines "new" as significantly different from existing products (new uses or combinations of existing knowledge or technologies), and "significantly improved" as changes in products that enhance the firm's performance (OECD, 2005: 48). New is "unique" and improvement is the "addition of a new feature". Both may be "incremental" (OECD, 2005: 47) but not "minor" (OECD, 2005: 17). In spite of these definitions, there is a perceived ambiguity between the terms new and significantly improved (OECD, 2016d: 10), and dissatisfaction with "significantly improved", due to "vagueness and value judgment". Significantly improved is "subjective and prone to different interpretations" (OECD, 2014b: 98).

To make matters more complicated, in the latest edition of the Oslo manual, the OECD suggests three levels of novelty: new to the firm, new to the market, new to the world (Oslo, 2005: 57-58). ${ }^{6}$ These nuances are difficult to interpret. To a young firm, everything is "new to the firm". At the opposite extreme, "new to the world" necessitates knowledge that many do not have: "It is questionable that the new to the world concept can be correctly reported" (OECD, 2014b: 97). In between, "new to the market" is just as doubtful a concept: "Whether the respondents to innovation surveys are always sufficiently informed about the activities of the potential competitors" is questionable (OECD, 2016c: 17). Yet the OECD now considers suggesting that "Innovation has to be at least new to the market...then ask about new to the firm" be a second step only, not the main meaning of novelty (OECD, 2014b: 97).

A second challenge to the definition of innovation is the concept of implementation. Implementation is currently defined is dual terms. It includes both the production (and commercialization) and the use of new inventions, two entirely different concepts. "An innovation ... must have been implemented. A new or improved product is

\footnotetext{
${ }^{6}$ Such a classification is not really new. One can find similar ones in the 1970s. For example, Thomas Robertson, professor of marketing, distinguished several criteria for newness, as found in the literature on innovation: newness from existing products (radical or incremental), newness in time (introduction to the
} 
implemented when it is introduced on the market. New processes, marketing methods or organizational methods are implemented when they are brought into actual use in the firm's operations" (OECD, 2005: 47). This duality existed in the very first definitions of innovation from the 1960s (e.g.: OECD, 1968). Use is not uncontested. In general, introduction to the market is agreed on. But to many, use or diffusion (of an invention from others or from outside and used elsewhere) is imitation not innovation (Godin, 2016).

Nevertheless, it may be judicious to separate these two dimensions of innovation and make them into two types or sub-categories of innovation. But this solution is not really discussed, only considered in passing (OECD, 2016d: 10). The issue of implementation is discussed using other terms. One is "intention". Innovation is deliberate action that is planned and purpose oriented" (OECD, 2016c: 5). Commercial success, "brought to a successful ending", is another option discussed to define implementation. However, the difficulty remains that "a large proportion of respondents have a nuanced concept of success": failure is a relevant experience or stage of innovation (OECD, 2014b: 99).

A third challenge is the types of innovation. The Oslo manual defines four types of innovation: product (good or service), process (production or delivery method), marketing methods (like design or packaging) and organization methods (like business practices and workplace organization) (OECD, 2005: 48-52). It is easy for the questionnaire respondent to consider product innovation, generally understood with a reference to (advanced) technology - although technology is a term used in "ambiguous ways" (OECD, 2014b: 102), a "word [that] portray[s] different things to different people" (OECD, 2012: 12), and a word deleted from the definition in the latest edition of the Oslo manual. However, process innovation is "fundamentally undistinguishable" from a broad set of organizational and marketing innovations, particularly in services (OECD, 2014b: 100). There is "unease with the concept of marketing innovation" too (OECD, 2014b: 101). All in all, and despite 10 pages of distinctions in the Oslo manual (OECD, 2005: 47-57), there is confusion between product innovation and process innovation, between

market), newness in terms of sales level, newness to the customer (subjective perception) (Robertson, 1971: 4-7). 
process innovation and organizational innovation, and between organizational innovation and marketing innovation. Few can come up with examples of organizational innovation, and marketing innovation is most often not seen as innovation. The OECD is thinking about recommending the combining of process, organizational and marketing innovation into one category (and making them into sub-items), and reducing types of innovations to two: product and process (OECD, 2014b: 101).

I suggest that one basis for the above three challenges is the fact that the definition of innovation is perhaps not generic enough, at least not as generic as the definition of research in the Frascati manual. The very first edition of the Oslo manual (1992) was concerned with only one type of innovation, or a "narrow definition" of innovation, as the OECD put it (OECD, 2005: 46): technological innovation (products and processes). Other types were added gradually in the following editions, making the definition the sum of ad hoc additions to an already restricted definition: technological, organizational and marketing innovations.

The OECD definition of innovation explicitly names and includes types of innovation, whereas for research and the Frascati manual, types are not part of the definition, but rather subcomponents or categories (basic, applied, development). A more generic definition of innovation would resemble those below: equipped with such a definition, everything else (types of innovation) would fall into subcategories and not into the definition, as the Frascati manual does regarding research: ${ }^{7}$

Any thought, behavior, or thing that is new because it is qualitatively different from existing forms (Barnett, 1953: 7).

An idea, practice or object that is perceived as new by an individual (Rogers, 1962: 13) or other unit of adoption (Rogers, 1983: 11).

Still another reason for the confusion arises from the fact that the concept of innovation admits of many meanings. One is a noun. The first edition of the Oslo manual

\footnotetext{
7 In 1969, the OECD Center for Educational Research and Innovation (CERI) offered a more generic definition (although limited to education) than that of the Oslo manual: "Attempts at change in an educational system which are consciously and purposefully directed with the aim of improving the present system" (OECD, 1969: 13). Types of innovation included in the definition are organizational innovation, technological innovation and curricular innovation (OECD, 1969: 50-54).
} 
understood (technological) innovation as "new products and processes". ${ }^{8}$ Similarly, the following edition made it a qualified noun: "implemented technologically new products and processes”. ${ }^{9}$ The latest edition turned innovation into a verb. Innovation is the "implementation" of new products and processes - and other types of invention. ${ }^{10}$ To be sure, the definitions of innovation as a noun are always followed with an addendum on implementation meaning introduced to the market or used in production. But now the verb form is stressed. The fuzziness of the definitions is nowhere more evident than in the following: "An innovation...is the implementation of one or more types of innovation" (OECD, 2005: 46). This is a bit circular, unless we change the last occurrence of the word innovation to invention. Here, the manual uses innovation in two different senses in the same phrase: as a noun and as a verb.

Still a third meaning of innovation is a process, namely a series of steps or activities. "Innovation activities are all scientific, technological, organizational, financial and commercial steps which actually, or which are intended to, lead to the implementation of innovations (OECD, 2005: 47). ${ }^{11}$ Such a meaning has a long history, again going back to the $1960 \mathrm{~s}-70 \mathrm{~s},{ }^{12}$ and is present in the early editions of the Oslo

\footnotetext{
8 "Technological innovations comprise new products and processes and significant technological changes of products and processes. An innovation has been implemented if it has been introduced on the market (product innovation) or used within a production process (process innovation)" (OECD, 1992: para. 90).

9 "Technological product and process (TPP) innovations comprise implemented technologically new products and processes and significant technological improvements in products and processes. A TPP innovation has been implemented if it has been introduced on the market (product innovation) or used within a production process (process innovation)" (OECD, 1997: 31)

10 "An innovation is the implementation of a new or significantly improved product (good or service), or process, or a new marketing method, or a new organizational method (in business practice, workplace organization or external relations)" (OECD, 2005: 46). "An innovation...must have been implemented. A new or improved product is implemented when it is introduced on the market. New processes, marketing methods or organizational methods are implemented when they are brought into actual use in the firm's operations" (OECD, 2005: 47).

${ }^{11}$ To the latest edition of the Oslo manual, these activities are R\&D, acquisition of external knowledge and technology, acquisition of machinery, equipment and other capital goods, preparations for development and implementation (later phases of development not included in R\&D, like industrial design, engineering and set-up, trial production, patent and license work, market research, manufacturing start-up and testing, advertising) and training (required for implementation).

${ }^{12}$ Innovation is a process in three parts: invention, (initial) innovation ("when a firm introduces a new or improved product into the economy for the first time"), and (innovation by) imitation, later called diffusion (OECD, 1966: 9). The Pavitt and Wald study does not talk of process, but distinguishes the stages of invention, innovation and diffusion as "indispensable to understand the various economic policy implications of science and technology" (OECD, 1971: 19). "Technical innovation is defined as comprising those technical, industrial, commercial steps which lead to the successful marketing of new manufactured products and/or to the commercial use of technically new processes or equipment. These terms in fact define the concept of the innovation process" (OECD, $1978: 18$ ). According to the OECD, this process is
} 
manual as well. ${ }^{13}$ This meaning has a definite policy orientation. While the definition of innovation as implementation is result-oriented or outcome-oriented (the ultimate phase or output of innovation activities: marketed inventions), this one is policy-oriented. It identifies the steps and measures (actions) that need measurement for public policy (OECD, 1978).

From what I have documented above, the conceptual challenges involved in innovation surveys are many. Most of these were identified as early as 1993, and still remain unresolved (Godin, 2002). Whether the challenges are surmountable in the near term is difficult to say. In fact, in spite of the regular revisions of the Oslo manual, the difficulties have increased over time rather than diminished. A fourth edition of the Oslo manual is due in late 2017 or early 2018. Like the Frascati manual, a chapter devoted to concepts is envisaged.

\section{Conclusion}

OECD manuals are very complex documents. Even if they were simple, the respondents to national questionnaires do not take the time to read and make sense of the hundreds of pages on definitions, inclusions and exclusions needed to make sense of the concept to be measured. To make matters worse, in only a few decades, there has been “A very rapid succession of manual development and survey rounds” (OECD, 2012: 3-4), which makes rules difficult to follow consistently. Just to take one example, the types of innovation included in the concept of innovation have shifted from solely technological in 1992 to now include organizational and marketing innovation in the last edition (2005), with enormous difficulties of understanding, as discussed above. The scope of the

composed of four stages, "from invention to market": invention, prototype and development, technical and commercial feasibility studies, production. The 1981 edition of the Frascati manual included a definition of innovation for the first time, as follows: "Transformation of an idea into a new or improved salable product or operational process.... It involved all those activities, technical, commercial, and financial steps, other than $\mathrm{R} \& \mathrm{D}$, necessary for the successful development and marketing of a manufactured product and the commercial use of the processes and equipment...” (OECD, 1981: 15, 28).

13 "Innovations involve a series of scientific, technological, organisational, financial and commercial activities" (OECD, 1992: para. 90). “TPP innovations involve a series of scientific, technological, organisational, financial and commercial activities. The TPP innovating firm is one that has implemented technologically new or significantly technologically improved products or processes during the period under review” (OECD, 1997: 31). 
innovation surveys has been extended as well, from manufacturing to services, starting in 1997.

Manuals conventionalize but do not stabilize. An example is the recurring discrepancy between innovation and R\&D survey data (OECD, 2001; Francoz, 2000a). In spite of a standardized definition of $R \& D$, innovation surveys record significantly less R\&D activity than do standard R\&D surveys. In the case of the United States, the difference amounts to $\$ 5$ billion: the innovation survey reports $\$ 10.2$ billion spent on R\&D and the R\&D survey reports $\$ 15.2$ billion. ${ }^{14}$ "Questions and definitions are...interpreted differently in the context of a survey on business strategy or a survey primarily focused on R\&D” (OECD, 2014b: 96).

This does not seem dramatic to the statisticians. "We should not seek at any price to secure the same measurement of R\&D in both surveys, but rather understand and measure the divergences” (Francoz, 2000b: 5). To others, the correct number is that from the R\&D survey, not that from the innovation survey: "Several delegates did not see it as a problem to have different figures if it is recognized that the official figure for $R \& D$ should be taken from the R\&D survey" (Eurostat, 2002: 3). Nevertheless, efforts were envisaged for a while to obtain a single measure of innovation (OECD, 2000: 8; 2001: 3; Eurostat, 2001): either the two surveys could be combined, as envisaged by Eurostat - the main user of the innovation survey - or they could at the very least be conducted by the same agency, as the OECD seemed to prefer.

The main insight in this article is that methodological manuals conventionalize, but only for a time, and in very specific (cultural) contexts. They do not stabilize the definitions and the statistics based thereupon. First, standards are always subject to revision. Second, a standard remains a standard as long as it is accepted and used/followed/respected as such.

Despite the instability of standardized concepts, officials have been very influential on scholars' and vulgar conception/conceptualization of research and of innovation. In this paper I have studied the OECD, but the OECD was not the only public organization to study research and innovation early on. In the case of innovation, there were the UK Council for Science and Technology as well as the US Department of

\footnotetext{
${ }^{14}$ For similar data on Italy and Germany, see Sirilli (1999) and Grenzmann (2000).
} 
Commerce. Scholars followed - rather than preceded - public organizations. The definition of innovation from these organizations was adopted by scholars: the definition of innovation from the first report of the British Advisory Council for Science and Technology (1968) under Sir Solly Zuckerman was reproduced by researchers at the Science Policy Research Unit (SPRU) (SPRU, 1972; Rothwell and Robertson, 1973; Jervis, 1975; Pavitt and Walker, 1976), and the definition of innovation from the US Department of Commerce (1967) was used by researchers in the United States (Goldsmith, 1970; Twiss, 1974). These definitions, including those from the OECD, are still in use today.

One cannot record the history of concepts without studying officials as conceptual innovators. This is one central lesson from intellectual or conceptual history. Scholars are part of a social world, and borrow many of their concepts from this world. R\&D owes its widespread use in our vocabulary and in our theories to officials, as does innovation as either commercialization or process. 


\section{References}

Advisory Council for Science and Technology (1968), Technological Innovation in Britain, London: HMSO.

Ames, Edward (1961), Research, Invention, Development and Innovation, American Economic Review 51 (3): 370-381.

Anthony, Robert N. (1952), Management Controls in Industrial Research Organizations, Boston: Harvard University.

Barnett, Homer G. (1953), Innovation: The Basis of Cultural Change, New York: McGraw-Hill.

Becker, Selvin W. and Thomas L. Whisler (1967), The Innovative Organization: A Selective View of Current Theory and Research, Journal of Business 40 (4): 462-69.

Bush, Vannevar (1945), Science: The Endless Frontier, North Stratford: Ayer Co. [1995].

Census Bureau and National Science Foundation (2013), Finding from Early Stage Scoping Interviews in the United States: Final Report, Room Document no. 7, NESTI Meeting, 17-19 April, Paris: OECD.

Dearborn, De Witt C., Rose W. Kneznek and Robert N. Anthony (1953), Spending for Industrial Research, 1951-1952, Division of Research, Graduate School of Business Administration, Harvard University; US Department of Labor, Bureau of Labor Statistics.

Department of Commerce (1967), Technological Innovation: Its Environment and Management, Washington: USGPO.

Department of Defense (1953a), Scientific Research and Development in American Industry: A Study of Manpower and Costs, Department of Labor (Bureau of Labor Statistics) and Department of Defense (Research and Development Board), Washington, 1953.

Department of Defense (1953b), The Growth of Scientific R\&D, Office of the Secretary of Defense (R\&D), RDB 114/34, Washington.

Dominion Bureau of Statistics (1941), Survey of Scientific and Industrial Laboratories in Canada, Ottawa.

Eurostat (2001), Working Party Meeting on $R \& D$ and Innovation Statistics: Main Conclusions, 19-20 April.

Eurostat (2002), Summary Record of Eurostat/OECD Task Force Meeting 20 March 2002 to Discuss the Co-ordination of $R \& D$ Surveys and Innovation Surveys, Luxembourg.

Fabricant, Solomon, Michael Schiff, Joseph G. San Miguel and Shahid L. Ansari (1975), Accounting by Business Firms for Investment in Research and Development, Section III: The Literature on Accounting for Innovation (S. L. Ansari), New York: New York University Press.

Francoz, D. (2000a), Achieving Reliable Results From Innovation Surveys: Methodological Lessons Learned From Experience in OECD Member Countries, Communication presented to the Conference on Innovation and Enterprise Creation: Statistics and Indicators, Sophia Antipolis, 23-24 November 2000.

Francoz, D. (2000b), Measuring $R \& D$ in $R \& D$ and Innovation Surveys: Analysis of Causes of Divergence in Nine OECD Countries, DSTI/EAS/STP/NESTI (2000) 26.

Gilfillan, S. C. (1952), The Prediction of Technical Change, Review of Economics and Statistics, 34 (4): 368-85. 
Godin, Benoît (2002), The Rise of Innovation Surveys: Measuring a Fuzzy Concept, Project on the History and Sociology of STI Statistics, Montreal: INRS. Available at www.csiic.ca.

Godin, Benoît (2003), Measuring Science: Is There "Basic Research” Without Statistics? Social Science Information, 42 (1): 57-90.

Godin,. Benoît (2005), The Measurement of Science and Technology: 1920 to the Present, London: Routledge.

Godin, Benoît (2006a), On the Origins of Bibliometrics, Scientometrics, 68 (1); 109-133.

Godin, Benoît (2006b), Research and Development: How the “D” got into R\&D, Science and Public Policy, 33 (1): 59-76

Godin, Benoît (2006c), The Linear Model of Innovation: The Historical Construction of an Analytical Framework, Science, Technology, and Human Values, 31 (6): 639-667.

Godin, Benoît (2007), From Eugenics to Scientometrics: Galton, Cattell, and Men of Science, Social Studies of Science, 37 (5): 691-728.

Godin, Benoît (2013), The Institutionalization of Statistics on Science, Revista Entornos, 26 (1): 43-53.

Godin, Benoît (2014), Innovation and Creativity: A Slogan, Nothing but a Slogan, in Cristiano Antonelli and Albert N. Link (eds), Routledge Handbook of the Economics of Knowledge, London/New York, Routledge: 7-19.

Godin, Benoît (2015), Innovation Contested: the Idea of Innovation over the Centuries, London: Routledge.

Godin, Benoît (2016), Why Is Imitation not Innovation, in Benoît Godin and Dominique Vinck (eds.), Reflexive Innovation: Alternative Approaches to the Pro-innovation Bias, London: Edward Elgar, Forthcoming.

Godin, Benoît and Désirée Schauz (2016), The Changing Identity of Research: A Cultural and Conceptual History, History of Science, Forthcoming.

Goldsmith, Maurice M. (1970), Introduction, in Maurice M. Goldsmith (ed.), Technological Innovation and the Economy, London/New York: Wiley: xiii-xvii.

Grenzmann, C. (2000), Differences in the Results of the R\&D Survey and Innovation Survey: Remark on the State of the Inquiry, DSTI/EAS/STP/NESTI/RD (2000) 24

Hildred, William H. and Leroy A. Bengston (1974), Surveying Investment in Innovation, University of Denver, Colorado.

Holland, Maurice and William Spraragen (1933), Research in Hard Times, Division of Engineering and Industrial Research, National Research Council: Washington.

Holt, K. (1971), "Social Innovation in Organizations", International Studies of Management \& Organization, 1 (3): 235.

Jervis, Paul (1975), "Innovation and Technology Transfer - The Roles and Characteristics of Individuals”, IEEE Transactions on Engineering Management, EM-22 (1): 19-27.

Kelly, Patrick, Melvin Kranzberg, Frederic A. Rossini, Norman R. Baker, Fred A. Tarpley and Morris Mitzner (1975), Technological Innovation: A Critical Review of Current Knowledge, report to the National Science Foundation, Advanced Technology and Science Studies Group, Georgia Tech, Atlanta, Georgia.

Kimberly, John R. (1981), Managerial Innovation, in Paul C. Nystrom (ed.), Handbook of Organizational Design, London: Oxford University Press: 84-104. 
Knight, Kenneth E. (1967), A Descriptive Model of the Intra-Firm Innovation Process, Journal of Business 40: 478-96.

Machlup, Fritz (1962), The Supply of Inventors and Inventions, in National Bureau of Economic Research, The Rate and Direction of Inventive Activity, Princeton, Princeton University Press: 143-69.

Maclaurin, William Rupert (1955), Innovation and Capital Formation in Some American Industries, in National Bureau of Economic Research, Capital Formation and Economic Growth, Princeton, Princeton University Press: 551-578.

National Research Council (1920), Research Laboratories in Industrial Establishments of the United States of America, Bulletin of the National Research Council, March.

National Research Council (1941), Research: A National Resource (II): Industrial Research, National Resources Planning Board, Washington: USGPO.

National Resources Committee (1938), Research: A National Resource, Washington: USGPO.

OECD (1962), The Measurement of Scientific and Technical Activities: Proposed Standard Practice for Surveys of Research and Development, Paris: OECD.

OECD (1966), Government and Technical Innovation, Paris: OECD.

OECD (1968), Gaps in Technology: General Report, Paris: OECD.

OECD (1969), The Management of Innovation in Education, CERI, Paris: OECD.

OECD (1970), The Measurement of Scientific and Technical Activities: Proposed Standard Practice for Surveys of Research and Experimental Development, Paris: OECD.

OECD (1971), The Conditions for Success in Technological Innovation, Pavitt, K., and C. Wald, Paris: OECD.

OECD (1972), Ad Hoc Group on Industrial Innovation, Paris, OECD, DAS/SPR/72.32.

OECD (1976), The Measurement of Innovation-Related Activities in the Business Enterprise Sector, DSTI/SPR/76.44, Paris: OECD.

OECD (1978), Policies for the Stimulation of Industrial Innovation, Volume 1 (Analytical Report), Paris: OECD.

OECD (1981), The Measurement of Scientific and Technical Activities: Proposed Standard Practice for Surveys of Research and Experimental Development, Paris.

OECD (1992), OECD Proposed Guidelines for Collecting and Interpreting Innovation Data, Paris: OECD.

OECD (1997), Guidelines for Collecting and Interpreting Innovation Data, Paris: OECD. OECD (2000), Record of the NESTI Meeting, DSTI/EAS/STP/NEST/M (2000) 1.

OECD (2001), Assess Whether There Are Changes Needed as a Result of the Comparison of $R \& D$ Data Collected in $R \& D$ and in Innovations Surveys, DSTI/EAS/STP/NESTI (2001) 14/PART3.

OECD (2005), Oslo Manual: Guidelines for Collecting and Interpreting Innovation Data, Paris: OECD.

OECD (2012), The Cognitive Testing of Innovation Surveys: Preliminary Findings from a Review by NESTI, DSTI/EAS/STP/NESTI(2012)7, Paris: OECD

OECD (2013), Findings from the OECD/NESTI Scoping Cognitive Interviews on Business Innovation, DSTI/EAS/STP/NESTI(2013)6, Paris: OECD.

OECD (2014a), The Definition of R\&D in the Frascati Manual: Proposals by Frascati Revision Group 1, DSTI/EAS/STP/NESTI(2014)7, Paris: OECD. 
OECD (2014b), Findings from the OECD/NESTI Project on the Cognitive Testing of Innovation Survey Concepts, Definitions and Questions, DSTI/EAS/STP/NESTI(2014)19, Paris: OECD.

OECD (2014c), Measuring Public Sector Innovation: Proposals for Preliminary Measurement Guidelines, DSTI/EAS/STP/NESTI(2014)16, Paris: OECD.

OECD (2014d), Overview of the State of the Frascati Manual Revision Discussions: A Note by the Secretariat, DSTI/EAS/STP/NESTI(2014)5, Paris: OECD.

OECD (2015), Frascati Manual: Guidelines for Collecting and Reporting Data on Research and Experimental Development, Paris: OECD.

OECD (2016a), Draft Summary of the OECD/NESTI-EUROSTAT Oslo Manual Revision Scoping, DSTI/EAS/STP/NESTI(2016)1, Paris: OECD.

OECD (2016b), Preliminary Proposals for the Oslo Manual (OM4), DSTI/EAS/STP/NESTI(2016)2/ANN3, Paris: OECD.

OECD (2016c), Review of the Oslo Manual's Basic Definitions: How to Get a Sound Grasp of Innovation?, DSTI/EAS/STP/NESTI(2016)2/ANN2, Paris: OECD.

OECD (2016d), Scoping the Revision of the Oslo Manual, DSTI/EAS/STP/NESTI(2016)2, Paris: OECD.

OECD (2016e), The Oslo Manual Review: Increasing the Manual's Relevance for Collecting Evidence on Innovation in a Changing World, DSTI/EAS/STP/NESTI(2016)2/ANN1, Paris: OECD.

Pavitt, Keith and William Walker (1976), Government Policies towards Industrial Innovation: A Review, Research Policy 5: 11-97.

Perazich, George and Philip M. Field (1940), Industrial Research and Changing Technology, Works Projects Administration, National Research Project, report no. M-4, Pennsylvania: Philadelphia.

Posner, Lawrence D. and Leon J. Rosenberg (1974), The Feasibility of Monitoring Expenditures for Technological Innovation, Practical Concepts Inc, Washington.

President's Scientific Research Board (PSRB) (1947), Science and Public Policy, Washington: USGPO.

Roberts, Robert E. and Charles A. Romine (1974), Investment in Innovation, Midwest Research Institute, Kansas City.

Robertson, Thomas S. (1971), Innovative Behavior and Communication, New York: Holt, Rinehart \& Winston.

Rogers, Everett M. (1962), Diffusion of Innovations, New York: Free Press.

Rogers, Everett M. (1972), Key Concepts and Models, in Robert A. Solo and Everett M. Rogers (eds.), Inducing Technological Change for Economic Growth and Development, East Lansing: Michigan State University Press: 85-101.

Rothwell, Roy and A. B. Robertson (1973), The Role of Communications in Technological Innovation, Research Policy 2: 204-25.

Scoville, Warren C. (1951), Spread of Techniques: Minority Migrations and the Diffusion of Technology, Journal of Economic History 11 (4): 347-60.

Shapley, Willis H. (1959), Problems of Definition, Concept, and Interpretation of Research and Development Statistics, in National Science Foundation, The Methodology of Statistics on $R \& D$, NSF 59-36, Washington: National Science Foundation: 7-15. 
SPRU (1972), Success and Failure in Industrial Innovation, Report on Project SAPPHO, London: Center for the Study of Industrial Innovation.

Sirilli, Georgio (1999), Old and New Paradigms in the Measurement of $R \& D$, DSTI/EAS/STP/NESTI (99) 13.

Twiss, Brian C. (1974), Managing Technological Innovation, London: Longman. 